\title{
Evaluation of anti-asthmatic and anti-cholinergic activity of ethanolic extract of Tectina grandis Linn. bark
}

\section{Deepali J. Jaybhaye*, Prashant S. Chaudhary, Shruti Chandra, Sukhmeen Johar}

Department of Pharmacology, Mahatma Gandhi Mission Hospital and Medical College, Aurangabad, Maharashtra, India

Received: 28 February 2020

Revised: 04 March 2020

Accepted: 05 March 2020

\section{*Correspondence:}

Dr. Deepali J. Jaybhaye,

Email: deepalijaybhaye@rediffmail.com

Copyright: (C) the author(s), publisher and licensee Medip Academy. This is an open-access article distributed under the terms of the Creative Commons Attribution Non-Commercial License, which permits unrestricted non-commercial use, distribution, and reproduction in any medium, provided the original work is properly cited.

\begin{abstract}
Background: Asthma is a chronic disease that affects approximately 300 million people worldwide. Tectona grandis Linn. bark, also known as Teak (English), is traditionally used to treat asthma. However, the scientific data on antiasthmatic and anti-cholinergic of this plant has got little attention. An attempt has been based on ethanolic extract of bark of Tectona grandis Linn. shown a tremendous effect on asthma when comparative study was done with normal and treated group.

Methods: The anti-asthmatic activity of a 95\% ethanol and 5\% distilled water extract of dried and fresh Tectona grandis Linn. bark, was evaluated against histamine and acetylcholine-induced preconvulsive dyspnea (PCD) in guinea pigs fasted for $24 \mathrm{~h}$ were exposed to an atomized fine mist of $2 \%$ histamine dihydrochloride and acetylcholine aerosol (dissolved in normal saline) using nebulizer at a pressure of $300 \mathrm{mmHg}$ in the histamine chamber $(24 \times 14 \times 24$ $\mathrm{cm}$, made of perplex glass. They were divided in groups Mepyramin $(8 \mathrm{mg} / \mathrm{kg})$ intraperitonially, atropine aerosol and Tectona grandis bark formulation $(2.5,5,10 \mathrm{gm} / \mathrm{kg})$ were administered orally $30 \mathrm{~min}$ prior to exposure. Animals, which did not develop typical asthma within 6 minutes, were taken as protected.

Results: Ethanolic extract of Tectona grandis Linn. bark at 5 and $10 \mathrm{gm} / \mathrm{kg}$ significantly reduce bronchoconstriction as compared to control group along with significant mast cell stabilization activity.

Conclusions: In conclusion, the present study shows that the ethanolic bark extract of Tectona grandis Linn. has potential antiasthamatic and antichlolinergic action in histamine and acetylcholine broncocontraction in guinea pigs.
\end{abstract}

Keywords: Anti-asthmatic, Anti-cholinergic, Tectona grandis Linn. bark extract

\section{INTRODUCTION}

Asthma is the inflammation of the airways which results in increased contractability of the bronchial smooth muscles. ${ }^{1,2}$ This narrowing of the airway which result wheezing. In asthama there is liberation of endogenous and intrinsic mediators like histamine, leukotrienes (LTs), bradykinin, prostaglandins (PGs), nitric oxide, platelet activating factors (PAF), chemokines and endothelin from mast cells during the allergic reactions which result inflammation of the air passages in the lungs. Worldwide incidence of bronchial asthama is $7-10 \% .^{3}$ Adrenergic drug is main modality of treatment. ${ }^{4}$ Triggered factors for inflammation of bronchus are various infections, dust, cold air, exercise, emotion, perfumes, chemical, environmental tobacco smoke and histamine. ${ }^{5}$ symptomatic relief is main goal of the treatment. In, India Ayurveda mentioned numerous herbs for therapeutic use in asthma. Tectona grandis Linn. (Verbenaceae) is one of them important plants. It is a large deciduous tree, distributed all over India. It is commonly known as Sagwan (Hindi), Saka (Sanskrit) and Teak tree (English). ${ }^{6}$ Its bark is acrid and used in the treatment of bronchitis, 
hyperacidity, constipation, diabetes, anthelmintic, leprosy and skin diseases. Methanol extract has shown antibacterial activity. ${ }^{6-8}$ According to literature Tectoionols A and B (apocarotenoids), napthaquino neanthraquinone glycoside, tectol, tectograndiol, lapachol, steroidal moieties and tannin are major components present in Tectona grandis which might be responsible for various medicinal use of herb. Although, there is no scientific proof of the efficacy of plant extracts for antiasthmatic activity with the use of histamine with guinea pig and also anticholinergic property also not known.

The aim of present study was to evaluate antiasthmatic effect of Tectona grandis antihistaminics with exploration of anticholinergic property.

\section{METHODS}

\section{Collection of plant materials}

The bark of Tectona grandis Linn. were collected from the outfield of Sewagram District, Wardha Maharashtra February-March 2007. The collected plant bark extract were deposited and shade dried in the Department of Pharmacology, Mahatma Gandhi Institute of Medical Sciences Sewagram Wardha.

\section{Drugs and chemicals}

Histamine dihydrochloride, acetylcholine chloride, atropine sulfate, mepyramine meleate, and toluidine blue were purchased from CAL Laboratories, supplied by Kasliwal Brothers, Indore. Histamine solution was freshly prepared in normal saline $(\mathrm{NaCl}, 8.5 \mathrm{gm} / \mathrm{l})$. All the other chemicals were of analytical grade.

\section{Extraction}

Bark of Tectona grandis were washed with distilled water to remove dirt and soil, and shade dried. The dried materials were powdered by mixture and passed through a 10-mesh sieve. ${ }^{6,9}$ Then 500 gm of plant bark powder was macerated with $95 \%$ of ethanol and $5 \%$ distilled water, after 24 hours of maceration, extraction done with 95\% ethanol with $5 \%$ distilled water in percolator after percolation for 48 hours. Extract was dried in fan so that solvents evaporated and get crude ethanol extract.

\section{Experimental animals}

Antihistaminic and anticholinergic studies were conducted on guinea pigs (350-500 gm) of either sex. For mast cell stabilization paradigm, adult Wistar albino rats weighing 140-160 gm of either sex were used. All the experimental animals were fed on commercial pellet diet (Poshak Ahar Pvt. Ltd. India). They were group housed under standard conditions of temperature $\left(22 \pm 20^{\circ} \mathrm{C}\right)$, relative humidity $(60 \pm 5 \%)$ and 12:12 light/dark cycle was maintain. They were divided in groups of six animals each. Group 1 was the saline fed group served as control Group 2 was treated with a standard drug. Group 3 was bark extract $2.5 \mathrm{gm} / \mathrm{kg}$ and Group 4 was bark extract 5 $\mathrm{gm} / \mathrm{kg}$. Group 5 was $10 \mathrm{gm} / \mathrm{kg}$ of bark extract. Before experimentation, the animals were kept on fast for 24 hours but water was given $a b$ de libitum. During experiments, animals were also observed for any alteration in their general behavior. All the experimental protocols were approved by the Institutional Animal Ethics Committee (IAEC).

\section{Preparation of plant extract}

Tectona grandis Linn. bark extract formulation was suspended in 1\% SCMC in distilled water and administered orally. The control animals were given an equivalent volume of SCMC vehicle. The standard group received Mepyramine spray and atropine sulphate I.P. ${ }^{10}$

\section{Phramacological screening (antiasthmatic paradigms)}

\section{Histamine-induced bronchospasm in guinea pigs}

The guinea pigs fasted for 24 hours were exposed to a $2 \%$ histamine dihydrochloride aerosol (dissolved in normal saline) using nebulizer with pressure of $300 \mathrm{mmHg}$ in the histamine chamber $(24 \times 14 \times 24 \mathrm{~cm}$, made of perplex glass). Guinea pigs which were exposed to histamine aerosol showed progressive signs of difficulty in breathing than followed by convulsions, asphyxia and death. The time required for development of convulsion is called pre-convulsion time (PCD). ${ }^{11-13}$ Preconvulsion time can be judge accurately by experience and observation. When animal reached to preconvulsion time, animal were removed from chamber and placed in fresh air to recover. In this experiment the criterion used was time for onset of dysponea and percent of protection from convulsant was calculated by the percentage protection offered by the standard and test drug against asphyxia was calculated, using the formula: Percentage protection= [(T2-T1)/T2] $\times 100$. Three days prior to the experiment screening was done and the animal who develop asthama within 3 minute with histamine were selected for the experiment, along with it we also given habituation practice to retain them in histamine chamber. Animals were divided in groups of six animals each. Mepyramine (8 $\mathrm{mg} / \mathrm{kg}$ ) administrated intraperitonially and Tectona grandis Linn. bark extract formulation $(2.5,5,10 \mathrm{gm} / \mathrm{kg})$ were administered orally 30 minutes prior to exposure. Animals, which did not develop typical asthma within 6 minutes were taken as protected.

\section{Acetylcholine- induced bronchospasm in guinea pigs}

Procedure was similar as describe above to the histamine aerosol study except that animals were exposed to aerosol of $0.5 \%$ acetylcholine in another set of animals $(n=6) .{ }^{14-16}$ Atropine sulphate $(2 \mathrm{mg} / \mathrm{kg})$ was used as a standard drug. Degranulation of mast cell carried out by compound $48 / 80$ it was the same method described by Kaley et al 
with little modification. ${ }^{2}$ Male albino rats were sacrificed by ketamine anesthesia. The albino rats were immediately injected with $15 \mathrm{ml}$ of prewarmed $\left(37^{\circ} \mathrm{C}\right)$ buffered salt solution $(\mathrm{NaCl} 137 \mathrm{mM}$; KCl $2.7 \mathrm{mM} ; \mathrm{MgCl} 2 ; 1 \mathrm{mM}$; $\mathrm{CaCl} 20.5 \mathrm{mM}$; $\mathrm{NaH}_{2} \mathrm{PO} 40.4 \mathrm{mM}$; Glucose $5.6 \mathrm{mM}$; HEPES $10 \mathrm{mM}$ ) into the peritoneal cavity, and massage was given gently for 90 seconds. Peritoneum was exposed by giving midline incision. Aspiration of pale fluid by using blunted plastic Pasteur pipette and collected in plastic centrifuge. It was centrifuged at 1000 rpm for 5 minutes, supernatant discarded to reveal a pale cell pellet. The cell pellets were re-suspended in fresh buffer and re-centrifuged. The centrifuged fluid was incubated with the test compounds or disodium cromoglycate, before challenge with compound 48/80. The incubated fluid spread over glass slides and the mast cells were stained with $1 \%$ toluidine blue and counterstained with $0.1 \%$ light green. After drying slides in air. Mast cells counted from randomly selected high power objective fields (450X). The effect of Tectona grandis on mast cells was studied by incubating the mast cells for 10 minutes with the above formulation in a concentration of $2.5,5$ and $10 \mathrm{gm} / \mathrm{ml}$ along with standard drug prednisone $(10 \mathrm{mg} / \mathrm{kg})$. After incubation it was exposed to degranulator, compound 48:80 $(10 \mu \mathrm{g} / \mathrm{ml})$ for 10 minutes, again mast cell were spread over glass slide. The percent degranulation of the mast cells was calculated. Compared degranulation with control and standard drug with Tectona grandis bark extract.

All data of the experiment was statistically analyzed by Dunnett's t-test and two way ANOVA.

\section{Acute toxicity test (determination of LD50) $)^{13,17}$}

For the acute toxicity (LD50) done by method describe by Kabore Adama. Albino mice (20-25 gm) of either sex were used. Doses of Tectona grandis Linn. bark extract 1, $2,4,8,16 \mathrm{gm} / \mathrm{kg}$ were administered orally, one dose for each group. The treated animals were monitored for 24 hours for mortality and general behaviour. On above dose there was no occurrence of any adverse effects in animals. So, from the result of the above step, three different doses of $2.5,5$ and $10 \mathrm{gm} / \mathrm{kg}$ were chosen and administered orally respectively to three groups of one mouse per group. The treated animals were again monitored for 24 hours.

\section{RESULTS}

The results of the present study revealed mast cell stabilization, antihistaminic and anti-cholinergic actions of Tectona grandis Linn. bark extract. In the mast cell stabilization paradigm, weight of granuloma was $220 \mathrm{mg}$. while in the plant extract group it was $120,96 \mathrm{mg}$ in dose of 5 and $10 \mathrm{gm} / \mathrm{kg}$ which is significant $(\mathrm{p}<0.001)$. Compound 48/80 (10 $\mu \mathrm{g} / \mathrm{ml})$ produced about $76 \%$ degranulation of mast cells. Pretreatment with prednisolone $(10 \mathrm{mg} / \mathrm{kg})$ and the herbal formulation $(5$ and $10 \mathrm{gm} / \mathrm{kg})$ significantly reduced $(\mathrm{p}<0.01)$ degranulation of mast cells as compared to compound 48/80-tretaed control group (Table 3) which give the protection of $54 \%, 89 \%, 97 \%$ protection. These results suggest that herbal formulation protects mast cells from compound 48/80-evoked degranulation.

Table 1: Effect of Tectona grandis Linn. formulation on histamine-aerosol in guinea pigs.

\begin{tabular}{|c|c|c|c|}
\hline Treatment & Dose & $\begin{array}{l}\text { Preconvulsion } \\
\text { time (seconds) }\end{array}$ & Protection \\
\hline Control & Saline & $120.2 \pm 3$ & -- \\
\hline Mepyramine & $\begin{array}{l}8 \mathrm{mg} / \mathrm{kg} \\
\text { i.p. }\end{array}$ & $560 \pm 3.4$ & 78 \\
\hline $\begin{array}{l}\text { Tectona } \\
\text { grandis dose I }\end{array}$ & $\begin{array}{l}2.5 \mathrm{gm} / \mathrm{kg} \\
\text { orally }\end{array}$ & $280 \pm 2.2$ & $58 *$ \\
\hline $\begin{array}{l}\text { Tectona } \\
\text { gandis dose II }\end{array}$ & $\begin{array}{l}5 \mathrm{gm} / \mathrm{kg} \\
\text { orally }\end{array}$ & $320 \pm 1.5$ & $63 *$ \\
\hline $\begin{array}{l}\text { Tcetona } \\
\text { grandis dose } \\
\text { III }\end{array}$ & $\begin{array}{l}10 \mathrm{gm} / \mathrm{kg} \\
\text { orally }\end{array}$ & $430 \pm 2.5$ & $72 * *$ \\
\hline $\begin{array}{l}\text { Tectona } \\
\text { grandis }+ \\
\text { mepyramine }\end{array}$ & $\begin{array}{l}10 \mathrm{gm} / \mathrm{kg} \\
\text { (orally) + } \\
8 \mathrm{mg} / \mathrm{kg} \\
\text { (i.p.) }\end{array}$ & $630 \pm 2.5$ & $81 * *$ \\
\hline
\end{tabular}

In the histamine aerosol study, the control animals showed convulsion during the first 3 minutes of the experiment was selected for experiment. Prior treatment of herbal formulation $(2.5,5,10 \mathrm{gm} / \mathrm{kg})$ protected the animals proconvulsant time was increase 280, 320, 430 seconds. In control group proconvulsant time was 120 second (Table 1). It shows that Tectona grandis bark extract has significant effect in bronchial asthma $(p<0.01)$. The development of asphyxia produced by histamine aerosol confirming that it has antihistaminic activity. The Tectona grandis bark extract has highly significant effect when it is used with standard drug the preconvulsant time was 630 second. Histamine had major role in asthma. ${ }^{2}$ The close resemblance of pulmonary responses to histamine challenge in both guinea pigs and humans, as well as the anaphylactic sensitization made this species the model of choice. In the present study, guinea pigs were used because of the extreme sensitivity of their airways to the primary mediators of bronchoconstriction, including histamine and leukotrienes, and their ability to be sensitized to foreign proteins.

Acetylcholine-aerosol provoked bronchoconstriction in all animals of control group preconvulsant time was 110 seconds, while it was significantly increases to 280. 320, 370 seconds in herbal formulation $(2.5,5$ and $10 \mathrm{gm} / \mathrm{kg}$ ) ( $<<0.01)$ from acetylcholine-induced bronchoconstriction. Atropine sulphate (a standard antimuscarinic drug, 2 $\mathrm{mg} / \mathrm{kg}$, i.p.) significantly prolonged pre-convulsion time which is 480 seconds $(\mathrm{p}<0.01)$ and protected animals from asphyxia (Table 2). 
Table 2: Effect of Tectona grandis Linn. extract on acetylcholine induced bronchospasm in guinea pigs.

\begin{tabular}{|llll|}
\hline $\begin{array}{l}\text { Treatment } \\
\text { Control }\end{array}$ & Saline & $\begin{array}{l}\text { Preconvulsion } \\
\text { time (seconds) }\end{array}$ & Protection \\
\hline $\begin{array}{l}\text { Atropine } \\
\text { sulphate }\end{array}$ & $\begin{array}{l}2 \mathrm{mg} / \mathrm{kg} \\
\text { (i.p.) }\end{array}$ & $480 \pm 3.4$ & 77 \\
\hline $\begin{array}{l}\text { Tectona } \\
\text { grandis } \\
\text { dose I }\end{array}$ & $\begin{array}{l}2.5 \mathrm{gm} / \mathrm{kg} \\
\text { orally }\end{array}$ & $280 \pm 2.2$ & $61 *$ \\
\hline $\begin{array}{l}\text { Tectona } \\
\text { gandis } \\
\text { dose II }\end{array}$ & $\begin{array}{l}5 \mathrm{gm} / \mathrm{kg} \\
\text { orally }\end{array}$ & $320 \pm 1.5$ & $65^{*}$ \\
\hline $\begin{array}{l}\text { Tcetona } \\
\text { grandis } \\
\text { dose III }\end{array}$ & $\begin{array}{l}10 \mathrm{gm} / \mathrm{kg} \\
\text { orally }\end{array}$ & $370 \pm 2.5$ & $70^{* *}$ \\
\hline $\begin{array}{l}\text { Tectona } \\
\text { grandis }+\end{array}$ & $\begin{array}{l}10 \mathrm{gm} / \mathrm{kg} \\
\text { atropine } \\
\text { orally+ } \\
\mathrm{mg} / \mathrm{kg} \mathrm{i.p.}\end{array}$ & $550 \pm 2.5$ & $80^{* *}$ \\
\hline *p value $<0.05 ; * \mathrm{p} \mathrm{value<0.001.}$ & \\
\hline
\end{tabular}

But when standard drug used with plant bark extract, the preconvulsant time markedly increases, it was 550 seconds. This shows when plant extract combine with standard drug has synergistic action.

Table 3: Effect of Tectona grandis Linn. extracts on mast cell.

\begin{tabular}{|llll|}
\hline Treatment & Dose i.p. & $\begin{array}{l}\text { Weight of } \\
\text { granuloma } \\
\text { (mg) }\end{array}$ & Protection \\
\hline $\begin{array}{lll}\text { Control } \\
\text { Prednosoline }\end{array}$ & Saline & $220 \pm 3$ & - \\
\hline $\begin{array}{l}\text { Tectona } \\
\text { grandis dose I }\end{array}$ & $2.5 \mathrm{gm} / \mathrm{kg}$ & $90 \pm 3.4$ & 90 \\
\hline $\begin{array}{l}\text { Tectona } \\
\text { gandis dose II }\end{array}$ & $5 \mathrm{gm} / \mathrm{kg}$ & $160 \pm 2.2$ & 47 \\
\hline $\begin{array}{l}\text { Tcetona } \\
\text { grandis dose } \\
\text { III }\end{array}$ & $10 \mathrm{gm} / \mathrm{kg}$ & $96 \pm 2.5$ & $89 * *$ \\
\hline $\begin{array}{l}\text { Tectona } \\
\text { grandis }+ \\
\text { Prednosoline }\end{array}$ & $\begin{array}{l}10 \mathrm{gm} / \mathrm{kg} \\
\mathrm{and} 10\end{array}$ & $60 \pm 2.5$ & $97 * * *$ \\
\hline mp value $<0.05 ; * * \mathrm{~kg}$ value $<0.001 ; * * * \mathrm{p}$ value $<0.0001$. \\
\hline
\end{tabular}

\section{DISCUSSION}

In bronchial asthma, there is injury to mast cells and basophiles by antigenic stimulation and causes release of histamine. Histamine which is liberated by mast cell destruction causing smooth muscle contraction, increased vascular permeability and mucus formation. Histamine provoke bronchoconstriction, it causes the bronchial hyperactivity. Mast cells with mediator is main factor for initiation of early phase of allergic reaction and also responsible for initiation of chronic allergic reaction. ${ }^{18}$ For the study of agonist and antagonist on bronchus and bronchial tree the contraction of tracheal chain in vitro is use. Guinea pig is very sensitive to histamine and it is ideal model for testing $\mathrm{H} 1$ antihistaminics drugs in histamine chamber. Guinea pig tracheal chain preparation is suitable for screening of the antihistaminic activity. ${ }^{18}$

In present study Tectona grandis Linn. bark extract also shows increase the preconvulsant time as compared to control in histamine induced bronchoconstriction. This shows that Tectona grandis has antihistaminics property.

In acetylcholine induced bronchoconstriction Tectona grandis also increase in preconvulsant time significantly. As the muscarinic receptors (M2) present on bronchus. ${ }^{19}$ This shows that Tectona grandis has anticholinergic activity also.

Result study on Tectona grandis Linn. suggest that, there was appreciable decrease in severity of symptoms of asthma and also simultaneously improvement in lung function parameters. Along with it Tectona grandis Linn. has significant mast cell stabilizing activity.

\section{CONCLUSION}

In conclusion, the results of present investigation suggest that, Tectona grandis Linn. bark extract formulation have significant bronchodilator activity against histamine and acetylcholine. However, further studies are suggested to establish molecular mechanism and also to isolate and characterize the active principles responsible for the action. Further study is ongoing to characterize the active principles of the extract which are responsible for antiasthmatic activity.

\section{Funding: No funding sources}

Conflict of interest: None declared

Ethical approval: The study was approved by the Institutional Ethics Committee

\section{REFERENCES}

1. Govindan S, Viswanathan S, Vijayasekaran V, Alagappan R. A pilot study on the clinical efficacy of Solanum xanthocarpum and Solanum trilobatum in bronchial asthma. J Ethnopharmacol. 1999;66(2):205-10.

2. Kirtikar KR, Basu BD. Indian Medicinal Plants. 2nd ed. Dehradun, India. Oriental Enterprises; 2001: 131134.

3. Rang HP, Dale MM and Ritter JM, Pharmacology. 4th ed. Harcourt publisher, New Delhi; 2001: 340348.

4. Michael D, Crowell, Estephan N, Zayat, Brian E, Lacy. The effects of an inhaled $\beta 2$-adrenergic agonist on lower esophageal function: A Dose-Response Study. Chest. 2017;151(2):520-1.

5. Kelly HW, Sorknes CA, Asthma. In: Dipiro JT, Talbert RL, Yee GC, Matzke TR, Wells BG, Posey 
LM, eds. Pharmacotherapy- A Pathophysiology. 6th Ed. The Macgrow- Hill New York; 2005: 504.

6. Goswami D, Sonawane LL, Nirmal SA, Patil MJ. Evaluation of antiasthmatic activity of Tectona grandis Linn. bark. Int J Pharm Sci Res. 2010;1(1):10-5.

7. Jaybhaye D, Varma S, Gagne N, Bonde V, Gite A, Bhosle D. Effect of Tectona grandis Linn. seeds on hair growth activity of albino mice. Int $\mathbf{J}$ Ayurveda Res. 2010;1(4):211-5.

8. Kaley G, Weiner R. Prostaglandin ' $E$ ' a potential mediator. Ann New York Acad Sci. 1971;180:347-8.

9. Armitage JB, Wetzel TA, Baumbach GG, Frank Z, inventors; Kearney, Trecker Corp, assignee. Spindle construction and dual transmission therefor. United States patent US 2,988,965. 1961 Jun 20.

10. Bousquet J, Peter KJ, William WB, Johnson M, Antonio MV. Asthma. Am J Respirat Crit Care Med. 2000;161(5)1720-45.

11. Madigan DG, Griffiths LL, Lynch MJ, Bruce RA, Kay S, Brownlee G. Para-aminosalicylic acid in tuberculosis; clinical and pharmacological aspects. Lancet. 1950:239-45.

12. Zhimmet I, Tashkin DP. Alternative medicines for allergy and asthma. J Allerg Clin Immunol. 2000;106:603-14.

13. Thomas G, Araujo CC, Duarte JC, Desouza DP. Bronchodilatory activity of an aqueous fraction of an ethanol extract of the leaves of Cissampelos sympodialis in guinea pigs. Phytomed. 1997;4:233-8.

14. Di-Rosa M, Giroud JP, Willoughby DA. Studies on the mediators of acute inflammatory response induced in rats in different sites of carrageenan and turpentine. J Pathol. 1971;104:15-29.

15. Horwitz RJ, Busse WW. Inflammation and asthma. Clin Chest Med. 1995; 16:583-620.

16. Kumar A, Ramu P. Effect of methanolic extract of Benincasa hispida against histamine and acetylcholine-induced bronchospasm in guinea pigs. Indian J Pharmacol. 2002;34:365-6.

17. Saraf MN, Patwardhan BK. Pharmacological studies on Sarcostemma brevistigma. Part II Bronchodilator activity. Indian Drugs. 1988;26:54-7.

18. Hajare R, Darvhekar VM, Shewale A, Patil V. Evaluation of antihistaminic activity of piper betel leaf in guinea pig. Afr J Phar Pharmacol. 2011;5(2):113-7.

19. Alfonzo MJ, De Alfonzo RG, Barnes PJ. Muscarinic receptor subtypes in airways. Life Sci. 1993;52(56):521-7.

Cite this article as: Jaybhaye DJ, Chaudhary PS, Chandra S, Johar S. Evaluation of anti-asthmatic and anti-cholinergic activity of ethanolic extract of Tectina grandis Linn bark. Int J Basic Clin Pharmacol 2020;9:572-6. 